\title{
THERAPEUTIC EFFECTS OF SUPPLEMENTED POPULAR AND LESS KNOWN HERBS AND THEIR COLLECTION ON DIABETIC RATS
}

\author{
By \\ Mohamed Samir El-Dashlouty \\ Fatma El-Zahraa Amin El-Sherif \\ Nutrition and Food Science Dept \\ Nutrition and Food Science Dept \\ Faculty of Home Economics \\ Menoufiya University \\ Sherif Sabry Ragab \\ Nutrition and Food Science Dept \\ Faculty of Home Economics \\ Menoufiya University \\ Faculty of Home Economics \\ Menoufiya University \\ Mai Mahmoud Al-Hosiny \\ Nutrition and Food Science Dept \\ Faculty of Home Economics \\ Menoufiya University
}

\section{Research Gournal Specific Fducation}

Faculty of Specific Education

gYansoura University

ISSUE NO. 30, APRIL. 2013

مجلة بحوث التربية النوعية ـ جامعة المنصورة

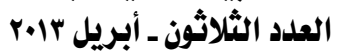




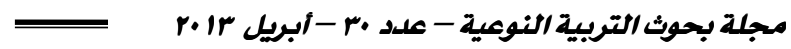

\section{THERAPEUTIC EFFECTS OF SUPPLEMENTED POPULAR AND LESS KNOWN HERBS AND THEIR COLLECTION ON DIABETIC RATS}

Mohamed Samir El-Dashlouty ${ }^{*}$

Sherif Sabry Ragab*
Fatma El-Zahraa Amin El-Sherif *

Mai Mahmoud Al-Hosiny Khafagy*

\section{Abstract}

Work was conducted to study the health and possible therapeutic effects of popular and less famous herbs on serum glucose and side effects of diabetes mellitus in alloxan injected rats. Sixty five mature male albino rats weighing 130-200g each divided into 13 groups (5 rats each) one kept as control (-) group while other 12 groups injected with alloxan. Herbs added at $7.5 \%$ to the basal diet given single or with bitter wood, bitter apple , harmala , garden cress, Dr.Mings tea and the mixture of them when unsupplemented or supplemented with wild Zommair and horse chestnut. Serum liver enzymes (ALT, AST, ALP), serum protein fractions(T.P, Alb, Glob \& A/G), serum lipids (TC, TG, HDL, LDL, VLDL\& atherogenic index"A.I"), serum creatinine, urea, uric acid, serum glucose as well as body weight gain(BWG), feed intake(FI) and feed efficiency ratio(FER)were recorded. The feeding trial continued for 28 days.

The obtained results revealed that all herbs used were of value for amelioration of diabetes mellitus and its side effects provided that the collection of them showed best results.

\footnotetext{
" Nutrition and Food Science Dept., Faculty of Home Economics, Minufiya University
} 


\section{THERAPEUTIC EFFECTS OF SUPPLEMENTED POPULAR AND LESS KNOWN HERBS AND THEIR COLLECTION ON DIABETIC RATS}

Mohamed Samir El-Dashlouty ${ }^{*}$

Sherif Sabry Ragab*
Fatma El-Zahraa Amin El-Sherif ${ }^{*}$

Mai Mahmoud Al-Hosiny Khafagy ${ }^{*}$

\section{INTRODUCTION}

Diabetes mellitus is a chronic disease that has been affected human kind Japan, Greece and Rome described the symptoms of the disease and usually included recommendations for nutraceutical treatment.The use of herbs as hypoglycemic is a major avenue in the Indian perspectives, which revire to be explored more effectively as there are so many literature on this aspect(Mukherjee et al.,2006) Blade et al.,(2006) reported that the use of medicinal plants is already widespread in Africa, particularly in Guinea where oral transmission of practices is part of the social ritnal.This type of treatment should be based on scientific evidence but very few studies have been conducted. The same may be said for Egypt where many herbs are suggested for treat . rent of ailments via oral transmission of practices .

Numerous herbs and supplements are already available for the treatment of diabetes and obesity, but many of these formulation have little evidence based research support to prove the efficacy of them . Numerous fat herbal collections are widely publicized but not grounded in evidence . Some of the herbs are popular as bitter apple at least in traditional medicine , but others as bitter wood \& harmala are less known, and deserve much more care by researchers. This Work was conducted to fill a part of this gap dealing with bitter wood, harmala as well as bitter apple, garden cress, Dr.Ming's tea, horse chestnut, wild oat as regards hyperglycemia and it's side effects . herbal formulation of all herbs was also studied to find out the possible synergism between them .

\footnotetext{
"Nutrition and Food Science Dept., Faculty of Home Economics, Minufiya University
} 


\section{Materials And Methods}

The tested main herbs in this study were : Bitter Wood (Picarasma excela L.) , Colocynth (Citrullus colocYnthis L.) , Harmala (Peganum harmala) Garden Cress (Lepidium sativum L.), Dr.Ming'sTea (a commercial herbal formulation), Horse Chestnut (Aesculus lippocastamum L.) for supplementation of above herbs to enhance immunity and resist against side effects of diabetes (Thomas,2000\&Mechler,2005). main herbs used singly and in combinations with wild oat plus horse chestnut. Diets contained always the basal diet of Reeves et al., (1993), provided that salt mixture was according to Hegested et al., (1941) and vitamin mixture was that of Campbell(1963).Besides the basal diet used for control (-) and one group of alloxan injected rats, main single herbs added at $7.5 \%$, while for main groups; in case of supplementation with main herb (wild oat\&horse chestnut) added at $2.5 \%$ level each(all composed $7.5 \%$ of basal diet).

Diabetes was induced in normal healthy rats by interaperitoneal injection of alloxan $150 \mathrm{mg} / \mathrm{kg}$ body weight, according to method described by (Desai and Bhide,1985),one weak after injection, fasting serum glucose determined, more than $160 \mathrm{mg} / \mathrm{dl}$ of serum glucose indicate diabetes mellitus (NDDG,1994).At the end of feeding trial (28 days) blood samples collected after 12 hourse fasting from the portal vein ; the rats sacrificed unde ether anesthetized.prepared serum red at $-20^{\prime} \mathrm{c}$ for analysis (Malhotra,2003).

During experiment the body weight gain (B.W.G\%),feed intake(FI) and feed efficiency ratio calculated after Chapman etal.,(1959). Internal organs were carefully removed washed in saline solution, dried with filter paper and weighted.

Biochemical analysis of serum included the following methods \& references: Total protein(Weichselbaum,1964); albumin (Domas and Biggs,1971);globulin(Total protein-albumin); oxaloacetic transaminase "AST" activity (Reitman and Frankel,1957); glutamic pyruvic transaminase "ALT" activity (Reitman and Frankel, 1957); alkaline phosphatase (ALP) activity (Rec,1972) ; creatinine (Henry,1974) ; urea (Patton,1977) ; uric 
acid(Fossati,1980) ; total cholesterol (TC)(Richmond,1973); triglycerides (TG)(Trinder,1969); high density lipoprotein cholesterol(HDL)(Richmond,1973) ; low density lipoprotein cholesterol(Richmond,1973) ; very low density lipoprotein cholesterol (VLDL) (Friedewald et al.,1972) ; atherogenic index (A.I.=VLDL+LDL/HDL (Kikuchi-Hayakawa et al.,1998); glucose (Trinder,1969).

Statistical analysis carried out using computerized SPSS program by one way ANOVA test using Duncan's multiple range test at $\mathrm{p}<0.05$ to indicate significant difference between groups (Snedecor and Cocran,1967).

\section{RESULTS AND DISCUSSION}

\section{I- Biological Results}

\section{( A )- Liver Function}

\section{a- serum protein fractions}

Table ( 1 ) illustrate the effect of some herbs supplementation on serum T.P, Alb, Glob and A/G ratio in rats pretreated with Alloxan. The mean value of T.P of control positive was significantly lower $(\mathrm{p}<0.05)$ than control negative, which were $6.30 \pm 0.17$ and $9.90 \pm 0.26 \mathrm{mg} / \mathrm{dl}$, respectively. Also, the value of diets A, B, C, D, Dr Ming's Tea and all herbs mixture ( at $7.5 \%$ level ) were significantly higher when compared to control positive.

As for Alb, the mean value of control positive was lower than control negative, which were $1.70 \pm 0.04$ and $7.10 \pm 0.15 \mathrm{mg} / \mathrm{dl}$, respectively . Whereas the values of diets A, B, C, D, Dr M|ing's tea and All herbs mixture ( at $7.5 \%$ level) were higher than control positive. Best group seems to be that of all herbs mixture . 


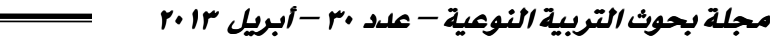

جدول 
The same table illustrated that the mean value of Glob of control positive was significantly higher $(\mathrm{p}<0.05)$ when compared to control negative, which were $4.60 \pm 0.137$ and $2.80 \pm 0.026 \mathrm{mg} / \mathrm{dl}$, respectively, Also the values of diets A, B, C, D, Dr Ming's tea and all herbs mixture ( at $7.5 \%$ level ) were lower than control positive.Best sample seems that of the supplemented garden cress with oats\&chestnut. As for $\mathrm{A} / \mathrm{G}$ ratio, the mean value of control positive was significantly lower $(\mathrm{p}<0.05)$ than control negative, which were $0.37 \pm 0.03$ and $2.54 \pm 0.05 \mathrm{mg} / \mathrm{dl}$ respectively, but the values of diets A, B, C, D, Dr ming's tea and all herbs mixture ( at $7.5 \%$ level ) were higher than control positive. Malhotra ( 2003 ), showed that alteration in $\mathrm{A} / \mathrm{G}$ ratio may occur due to the reduction in albumin and or elevation of globulin. However the ratio may be increased in some cases of biliary cirrhosis. From results of table (1) it could be observed that supplementation of bitter wood (diet A), bitter apple ( diet B), harmala ( diet C) and Dr.Mings tea (diet D) with oats (Avena) and horse chestnut improved mostly the levels of T.P, Alb, Glob \& A/G ratio . As reported by Thomas (2000), aescin compound in horse chestnut could trout a wide variety of inflammatory conditions, which are side effects of diabetes mellitus . As reported by Duke (1994) bitter wood may of value for diabetes . this was also reported for bitter apple (Davis \& Parke,2004), while harmala (Silva\& Abraham , 1981) has anti oxidant properties . Garden cress (Habb Alrashad) is recommended for diabetics (Muller\&Mechler, 2005). Dr Ming's Chinese herbal tea (Tomoyoshi , 2005) is advised for weight loss . But as found from table (1) it corrected the disorder of serum protein fractions due to diabetes . Data of table (1) indicated $A / G$ garden cress as single plant showed best result for serum protein fractions of diabetic rat , but when combined with oats \& chestnut best group was that of all herb mixture. The preference of all herb mixture reveals that certain synergism appeared when using all plants together . It is worthy mentioning that T.P of all herbs mixture was even less than the control (-) rats .

\section{b-serum liver enzymes}

Table (2) illustrate the effect of some unsublemented and supplemented diets on serum ALT, AST, ALP, and AST/ALT ratio on 
diabetic rat groups. As shown the mean value of AST of control positive was significantly higher $(\mathrm{p}<0.05)$ when compared to control negative which were $145.00 \pm 4.58$ and $42.00 \pm 2.05 \mathrm{U} / \mathrm{L}$, respectively. Also the value of diets A, B, C, D, Dr Ming's tea and all herbs mixture ( at $7.5 \%$ level ) were significantly lower when compared to control positive. At the same time ALT of control positive group was significantly higher $(\mathrm{p}<0.05)$ as compared to control negative rats being $40.00 \pm 2.65$ and $18.00 \pm 0.87 \mathrm{U} / \mathrm{L}$, respectively, Also the value of diets A, B, C, D, Dr Ming's tea and all herbs mixture (at $7.5 \%$ level ) were significantly lower when compared to control positive rats.

As shown in table (2) the mean value of AST/ALT ratio of control positive was significantly higher $(\mathrm{p}<0.05)$ when compared to control negative group which were $3.63 \pm 0.092$ and $2.33 \pm 0.061$ respectively . Also the values of diets A, B, C, D, Dr Ming's tea and all herbs mixture (at 7.5\% level) were significantly lower as compared to control positive group.

In this concern, Gaw et al., (2004), reported that raised activities of the amino transfrases (AST and ALT) indicate hepato cellular damage .

From results of present work, it can be observed that AST level of control positive was higher than for all diets and the control negative This was ( Table 2 ) also recorded for ALT. Moreover, all diets ( alone \& mixture) had favourable effect on ALT and AST.This result agreed with that of Leung and Foster (1996) ; Hurley et al ., (1998) ; Weiss and Fintelmann (2000) and Singh and Panada (2005) working on traditional herbal medicine. 
ב THERAPEUTIC EFFECTS OF SUPPLEMENTED POPULAR AND LESS KNOWN HERBS جدولr 
As shown in table (2) the mean value of ALP of control positive rats was significantly higher $(\mathrm{p}<0.05)$ when compared to control negative being $312.00 \pm 6.08$ and $132.00 \pm 3.21 \mathrm{U} / \mathrm{L}$, respectively. Also, the values of diets A, B, C, D, Dr Ming's tea and all herbs mixture (at 7.5\% level) were significantly lower comparing to control positive. Gaw et al., (2004), reported that ALP activity increases in diabetes mellitus and Liver disease (cirrhosis, tumours, infiltrativediseases) . Increased bilirubin concentration and increased ALP activity indicate the presence of cholestasis, ablockage in bile flow . From these results, it could be observed that ALP level of control positive was higher than control negative and than all diets; all diets had favorable effect on ALP . This result supported with data of ESCOP (1997) ; Blumenthal (2000) and Mueller and Mechler (2005).It should be noted that liver function was improved when using bitter wood (Duke, 1994), and horse chestnut (Thomas , 2000), Other plants used in present study were apparently not tested befor for liver function disorders .

Finally results of table (2) indicated that regardless of supplementation ( and all herbs mixture ) best result obtained with garden cress diet considering AST, ALT\& ALP, harmala was the best for AST/ALT. Meanwhile, after supplementation best treatment was that of harmala considering all parameters (AST, ALT, ALP, AST/ALT) showing lowers values even when compared with the control (-) group . In general supplementation improved the action of different used plants, indicating the synergism . synergism action was also obvious, since best treatment of all was that of the all herbs mixture .

\section{( B )- Kidney Function}

Table (3) results illustrate the effect of diets and all herbs mixture supplementation for 28 days on serum creatinine, urea and uric acid in diabetic groups .As shown from the data the mean value of creatinine of control positive was higher than control negative , which were $1.20 \pm 0.044$ and $0.70 \pm 0.032 \mathrm{mg} / \mathrm{dl}$, respectively, also, the values of groups $\mathrm{A}, \mathrm{B}, \mathrm{C}, \mathrm{D}$, Dr Ming's tea and all herbs mixture (at 7.5\% level) were lower than control positive.Serum Urea of control positive was higher than control negative, 
$=$

which were $162.00 \pm 7.21$ and $37.00 \pm 2.45 \mathrm{mg} / \mathrm{dl}$, respectively. Also the values of diets A, B, C, D, Dr Ming's tea and all herbs mixture groups were lower than control positive. As for Uric acid of serum, the results showed that the mean value of control positive was higher than control negative , which were $3.50 \pm 0.22$ and $2.00 \pm 0.11 \mathrm{mg} / \mathrm{dl}$, respectively, also the values of groups A, B, C, D, Dr Ming's tea and all herbs mixture (at 7.5\% level) were lower than control positive. 


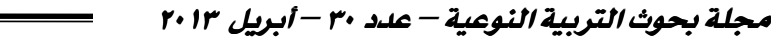

جدول 


\section{C- Lipids Fractions in Serum}

Table(4) illustrate the effect of diets and all herbs mixture supplementation for 28 days on serum TC, TG, HDLc, LDLc, VLDLc and A.I.ratio in rats pretreated with Alloxan.

As shown in this table, the mean value of TC of control positive was higher than control negative, which were $191.00 \pm 3.61$ and $142.00 \pm 2.64$ $\mathrm{mg} / \mathrm{dl}$, respectively, and the value of groups A, B, C, D, Dr Ming's tea and all herbs mixture (at $7.5 \%$ level) were significantly lower $(p<0.05)$ when compared to control positive. TG of control positive was higher than control negative which were $188.00 \pm 6.08$ and $121.00 \pm 3.41 \mathrm{mg} / \mathrm{dl}$, respectively, and the values of groups A, B, C, D, Dr Ming's tea and all herbs mixture (at $7.5 \%$ level) were lower than control positive.

As for HDLc, the mean value of control positive was lower than control negative, which were $68.00 \pm 1.73$ and $110.00 \pm 4.35 \mathrm{mg} / \mathrm{dl}$, respectively, as well as the values of groups A, B, C, D, Dr Ming's tea and all herbs mixture (at $7.5 \%$ level) were higher than control positive.

The same table illustrated that LDL of control positive was higher than control negative, which were $85.40 \pm 2.51$ and $7.80 \pm 0.26 \mathrm{mg} / \mathrm{dl}$, respectively. Whereas the values of groups A, B, C, D, Dr Ming's tea and all herbs mixture (at7.5\% level) were lower than control positive.

As for VLDLc, the results showed that mean value of control positive was higher than control negative, which were $37.60 \pm 2.42$ and $24.20 \pm 0.72$ $\mathrm{mg} / \mathrm{dl}$, respectively. Also the values of groups A, B, C, D, Dr Ming's tea and all herbs mixture (at $7.5 \%$ level) were lower than control positive. The same table illustrated that A.I.ratio of control positive was higher than control negative, which were $1.81 \pm 0.025$ and $0.29 \pm 0.017$ respectively . whereas the values of groups A, B, C, D, Dr Ming's tea and all herbs mixture (at 7.5\% level) were lower than control positive.

Rombeau and Rolandelli (2001), reported that diabetes mellitius disease lead to increased serum lipids, impaired lipoprotein synthesis, and fat maldigestion and malabsorption .From the results of present work, it can be observed that certain plant diets had favourable effect on serum lipids . 
Such results supported by Tomoyoshi (2005) ; Leung and Foster (1996) ; Blumenthal (2000) ; Singh and Panda (2005). In particular Duke (1994) reported the value of bitter wood for diabetic patients ,leading also to treatment of hypertention, which is related to atherosclerosis (high A.I). Also, Hey (1996) stated that harmala was beneficial for diabetes and hypertension patients. Muller\& Mechler (2005) indicated that oats is cholesterol and LDL lowering. Tomoyoshi (2005) reported that Dr Ming's Tea helps to get rid of wanted for in the body .

The results of table(4)show the lipids fractions of diabetic rats and effect of herbal formulations.

Data presented in table(4) revealed that diabetes mellitus resulted in the increase of TC\&TG, while HDL reduced .Due to treatments the reverse was found.

\section{D-Serum glucose}

Table (5) illustrate the effect of diets and all herbs mixture supplementation for 28 days on serum glucose in rats pretreated with alloxan injection. As shown in this table, the mean value of serum glucose of control positive was higher than control negative, which were $169.00 \pm 3.46$ and $75.00 \pm 1.80 \mathrm{mg} / \mathrm{dl}$, respectively, and the value of groups A, B, C, D, Dr Ming's tea and all herbs mixture (at 7.5\% level) were significantly lower $(\mathrm{P}<0.05)$ when compared to control positive.

All treatments lowered serum glucose even to a less level than that of the healthy control(-) rats. Supplementation with uncultivated oats and horse chestnut increased the lowering effect of the diet, indicating a synergistic effect . This was also ready seen ( Synergism ) when knowing that all herbs mixture reduced the serum glucose compared to any other single plant, provided that similar results obtained for both all herbs mixture and bitter apple groups .

According to Duke (1994) bitter wood have a curing effect for diabetes mellitus. This was also reported by Davis and Parke (2004) for bitter apple. Garden cress ( Hurley et al., 1998 ) was also beneficial for diabetes mellitus . According to Srinivan et al., (2005) horse chestnut is a 
hypoglycemic agent. It is evident (Table 1-5) that the tested plants not only ameliorated or prevented the increase of serum glucose, but also was healing for liver, renal and lipid profile disorders ; i.e. the side effects of diabetes mellitus disease . 


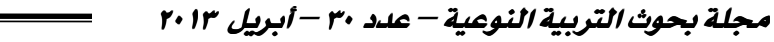

جدول 
جدول 0، 


\section{Biological Parameters}

a- Body weight gain (BWG), Feed intake (FI) and Feed efficiency ratio (FER).

Table (6) results show the effect of diets and all herbs mixture supplementation for 28 days on BWG, FI and FER in rats pretreated with alloxan. As shown the mean value of BWG of control positive was lower than control negative, which were $-0.36 \pm 0.0026$ and $0.076 \pm 0.0017$, respectively .but the value of groups A, B, C, D, Dr Ming's tea and all herbs mixture (at $7.5 \%$ level) were higher significantly $(p<0.05)$ when compared to control positive.

The mean value of FI of control positive was lower than control negative, which were $6.50 \pm 0.050$ and $6.90 \pm 0.010 \mathrm{~g}$, respectively .whereas the values of groups A, B, C, D and Dr Ming's tea (at 7.5\% level) were higher than control positive. But the value of all herbs mixture was higher than control positive by mean $17.77 \pm 0.039 \mathrm{~g}$, respectively.

FER of control positive was lower significantly $(p<0.05)$ when compared to control negative, which were $-0.06 \pm 0.0007$ and $0.011 \pm 0.005$, respectively .but, the values of groups A, B, C, D, Dr Ming's tea and all herbs mixture (at $7.5 \%$ level) were higher than control positive.

\section{B- Internal organs weight}

Table (7) shows the effect of feeding with herbs and supplementation with oat and chestnut for 28 days on lungs weight, mean value of lungs weight of control positive was higher than control negative, which were $1.22 \pm 0.039$ and $0.49 \pm 0.024 \mathrm{~g}$, respectively. Also, all values of groups A, B, C, D, Dr Ming's tea and all herbs mixture (at $7.5 \%$ level) were lower than control positive.

As for spleen weight the results showed that mean value of control positive was higher than control negative, which were $0.84 \pm 0.020$ and $0.28 \pm 0.010 \mathrm{~g}$, respectively .Also, the values of groups A, B, C, D, Dr Ming's tea and all herbs mixture (at $7.5 \%$ level) were lower than control positive. 
The mean value of heart weight of control positive was higher than control negative, which were $0.61 \pm 0.019$ and $0.20 \pm 0.012 \mathrm{~g}$, respectively , whereas the values of herbs groups A, B, C, D, Dr Ming's tea and all herbs mixture (at 7.5\% level) were lower than control positive.

As for kidney weight the results showed that mean value of control positive was higher than control negative, which were $1.42 \pm 0.019$ and $0.52 \pm 0.015 \mathrm{~g}$, respectively .Also, the values of herbs groups A, B, C, D, Dr Ming's tea and all herbs mixture (at $7.5 \%$ level) were lower than control positive.

This indicated that diets of present work ameliorated the inflammation in internal organs as side effect of diabetes mellitus. Such improvement was evident since ; most cases the all herbal mixture showed BWG, FI, FER and internal organs weights, being equal and sometimes better than that recorded for healthy control(-) rats. It is worth mentioning that biochemical changes ( Tables 1-5 ) also supported such openion. 


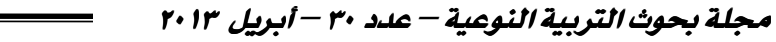

جدول 


\section{References}

- Balde, N.M.; Youla, A.; Balde, M.D.; Kake, A.; Diallo, M.M.;Balde, M.A.; and Mangendre, D. (2006): Herbal medicine and reatment of diabetes in Africa: An example from Guinea.Diabetes Metab. , 32 (2): 171-175.

- Blumenthal, M. (2000): Herbal Medicine: Expanded Commission E Monographs. American Botanical Council.

- Campbell, J. A.(1963): Methodology of Protein Evaluation. RAG Nutr.,Document R.10, Led . 37. June Meeting, New york .

- Chapman, D. G.; Castilla, R. and Campbell, J. A. (1959): Evaluation of Protein in Food. I. A method for the deterinination of protein efficiency ratio. Can. J. Biochem. Phosiol., 37: 679-686.

- Davis, N. and Parke, C. (2004): Manual of Therapeutics.PP. 62 - 266. Desai,N.S. and Bhide ,S.A. (1985) :Hypoglycemic effect of Hantitonia Suaveolens.Indian .J.Med .,81:86-91.

- Doumas , B.T. and Biggs, H.G. (1971): Albumin standard and measurement of serum albumin with bromocresol green .Clin . Chem. , 31:78.

- Duke, J.A. (1994): CRC Handbook OF Medicinal Herbs. CRC PRESS.

- SCOP (European Scientific Cooperative on Phytotherapy) (1997): Rosmarin folium. Monographs on the Medicinal ses of Plant Drugs. Exeter, U. K. : European Scientific Cooperative on phytotherapy.

- Fossati ,P.C. (1980) : Uric acid enzymatic colorimetric method .J of Clin., Chem, 26( 2):227-273.

- Friedewald, W. T. ; Leve, R.I. and Fredrickson , D.S.(1972): Estimation of concentration of low density lipoproteins separated by three different methods .Clin .Chem., 18:499- 502 .

- Gaw, A.; Murphy. M. J. ; Gowan, R. A.; O'Reilly, D. J.; ewart, M. J. and Sheperd, J. (2004): Clinical Biochemistry.Third Edition. Elsevier limited: Churchill Livingstone.

- Hegsted, D.; Mills, R. and Perkins, E. (1941): Salt mixture. J. Biol. Chem., 138: 459.

- Henry,R.J.(1974):Creatinine Colorimetric Method .J.Harper an ow.2 nd Edition .p.525. Hey, B. (1996): The Illustrated Book of Herbs. New Holland Publishers, LTD. 
- Hurely, J.; Carr, A.; Cassidy, C.; Hylton, W., Cohen, E.; Kowalchik, C.; Decenzo, A.; Milius, S.; Hunt, M. and Wilson, K. (1998): RoDale's Illustrated Encyclopedia of Herbs. Rodale Press, Inc. Pennsylvania.

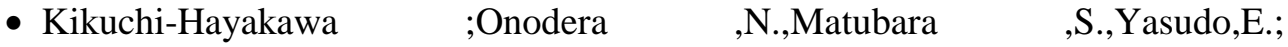
Chonan,O.,Takahashi,R. and Ishikawa ,F.(1998): Effect of soya milk on lipid metabolism in aged ovariectomized rats. BioScience Biotechnology and Biochemistry ,62(9):1688.

- Leung, A. Y. and Foster, S. (1996): Encylopedia of Common Natural Ingredients Used in Food, Drugs and Cosmetics. Second Edition. John Wiley \& Sons, INC.

- Malhotra,V.K.(2003):Practical Biochemistry for students ,Fourth Edition ,Jaypee Brothers Medical Publishers (P) LTD,New Delhi.

- Mueller, M. S. and Mechler, E. (2005): Medicinal Plants in ropical Countries. Thieme. Stuttgart. NewYork.

- Mukherjee, P.K .; Maiti , K .; Mukherjee , K . and Houghton, P .J.(2006): Leads from Indian medicinal plants with ypoglycemic potentials. J. of Ethnopharmacol ., 106(1):1-28.

- NDDG(1994):National Diabbetes Data Group:Classification and diagnosis of diabetes mellitus and other categories of glucose intolerance.Diabetes ,28: 10391057.

- Patton,C.J. (1977): Urea enzymatic method. J .of Anal . Chem. , 49:464-546.

- REC. G. S .CC. (DGKC) (1972) : Alkaline PhosphataseKinetic Method . J.of Clin . Chem. Clin .Biochem., 10.182.

- Reitman S.and Frankel , S .(1957):Colorimetric determination of serum transaminase .An .J .Clin .Path .,28:56-63.

- Reeves, P. G.; Nielson, F. H. and Fahmy, G. C.(1993): Reports of the American Institute of Nutrition, Adhoc Wiling Committee on Reformulation of the AIN 93 Rodent Diet. J. Nutri., 123: 1939-1951.

- Richmond,W. (1973) : Colorimetric determination of total cholesterol and high density lipoprotein . J .of Clin .Chem. , 19:1350-1356

- Rombeau, J. L. and Rolandelli, R. H. (2001): Clinical Nutrition Parenteral. Third Edition. W. B. Saunders Company.

- Silva , F . and Abraham, A ., ( 1981 ) : The Potentiality of the Israeli flora for medicinal purposes . Fitoterapia, $52: 195-200$. 
- Singh, M. P. and Panda, H. (2005): Medicinal Herbs with Their Formulations. Vol.1. Daya Publishing House. Delhi.

- Snedecor, G. W. and Cochran, W. G. ( 1967 ) : Statistical Methods. 6th Ed. Iowa State University Press. Ames. Lowa. USA.

- Srinivan , K . ; George , M . and Weiss , R . ( 2005 ) : Poland Food In the management of diabetes mellitus : Spices as beneficial antidiabetic food adjuncts . Inrernational Journal of Food Sciences and Nutrition, 56 ( 6 ): 399 - 414.

- Thomas, S. C. (2000): Medicinal Plants Culture, Utilization and Phytopharmacology. Technomic. Publishing Company. Inc., USA.

- Tomoyoshi, H.(2005): Effectiveness and Safety of Dr Ming's Tea in the treatment of obese, diabetic and hyperlipidemic rats.Preventive Medicine Journal, 105(8):763-772.

- Trinder,P. (1969): Glucose \& triglycerides enzymatic colorimetric methods . J .of Ann. Clin.Biochem. , 6:24 -27.

- Weichselbaum, C.T.E. (1964): An accurate and rapid method for the determination of protein in small amounts of blood serum and plasma. Amer .J . Clin .Path ., 16:40.

- Weiss, R. F. and Fintelmann, V. (2000): Herbal Medicine. Second Edition, Thieme. Stuttgart. NewYork. 


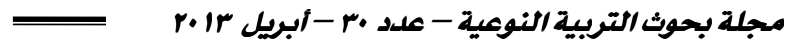

\section{التأثيرات العلاجية والمناعية لبعض الأعشاب عند استخداهها}

\section{في تغذية الفئران البيضاء المابة بمرض البـول السكري}

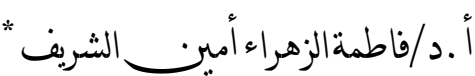

م.م/محممد الحسينحخفاح"

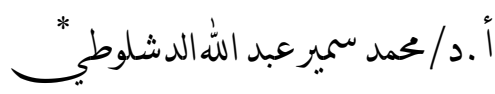

أ م.د/شريف صبريرجت

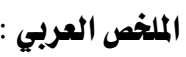

تم إجراء الدراسة الحالية لمعرفة التأثيرات العلاجية والمناعية لبعض الأعشاب علسي الفئران

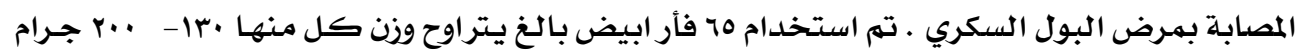

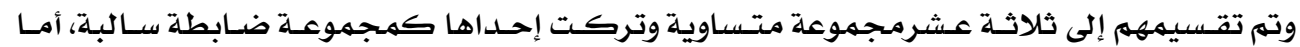

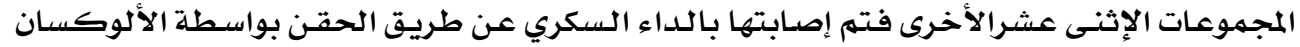

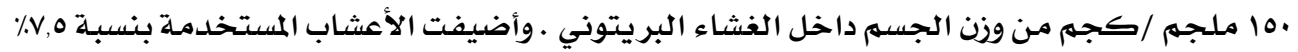

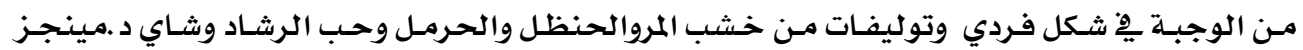

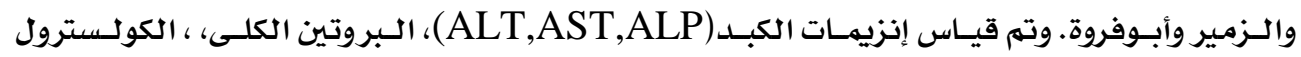

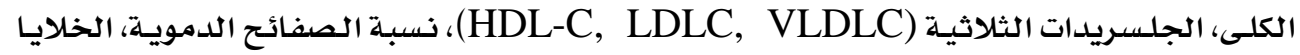

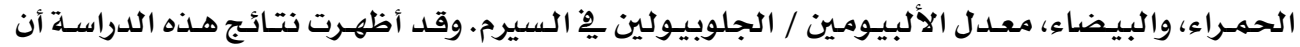

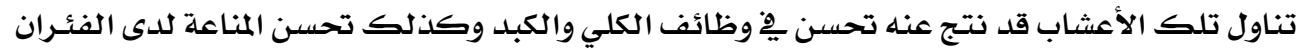

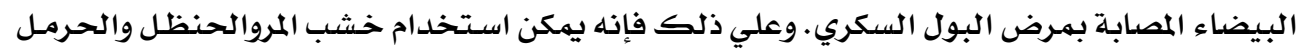

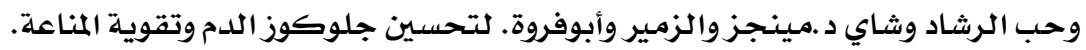

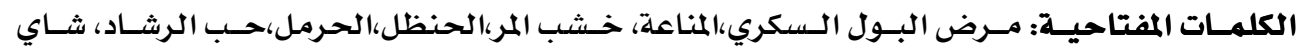
د.مينجز، الزمير، أبوفروة. 